\title{
SELECTION OF SHIELDING GAS FOR MECHANIZED ARC WELDING OF DISSIMILAR STEELS
}

\author{
V.P. ELAGIN \\ E.O. Paton Electric Welding Institute, NASU \\ 11 Bozhenko Str., 03680, Kiev, Ukraine. E-mail: office@paton.kiev.ua
}

\begin{abstract}
Mechanized multilayer MIG / MAG welding by high-alloy wires is associated with the feasibility of formation of lacks of fusion and slag pieces in weld metal. Therefore, the improvement of technology, in particular the selection of shielding gas composition, is urgent. Feasibility of application of mixtures $\mathrm{CO}_{2}+3 \% \mathrm{~N}_{2}$ and $\mathrm{CO}_{2}+3 \% \mathrm{~N}_{2}+0.5 \% \mathrm{O}_{2}$ as a shielding gas in mechanized arc welding of dissimilar steels is shown. It is shown that the metal oxidation occurs mainly in the inter-dendrite regions, intensity of which is increased with increase in amount of nickel in the welding wire. Weld metal alloying with nitrogen does not change the intensity of metal oxidation process and almost has no influence on slag crust removal from the deposited metal surface. 17 Ref., 2 Tables, 3 Figures.
\end{abstract}

$\boldsymbol{K} \boldsymbol{e} \boldsymbol{y} \boldsymbol{w} \boldsymbol{O} \boldsymbol{r} \boldsymbol{d} \boldsymbol{s}:$ mechanized arc welding, shielding gas, $\mathrm{CO}_{2}$, nitrogen, gas mixtures, high-alloy weld metal, slag crust, spinels, alloying with nitrogen

Mechanized shielded-gas arc welding by high-alloy wire is peculiar by high metal susceptibility to oxidation in welding zone and formation of lacks of fusion and slag pieces in weld [1]. In argon welding this is caused by a low stability of welding arc, leading to violation of welding process and gas shielding, and in mixture of argon with $\mathrm{CO}_{2}$ or oxygen it is caused by metal oxidation by the shielding gas proper. The nitrogencontaining gas, namely nitrogen [2], argon mixtures or $\mathrm{CO}_{2}$ with nitrogen [3] or with air $[4,5]$ is also used, but here the risk of pore formation in weld is occurred [4,6]. Large selection of different compositions of shielding gases for almost similar technological variants proves that the development of gas mixtures, and also the developing of theory of gas-shielded welding process and still continued, that is confirmed by numerous publications on this subject $[7,8]$.

Beside the shielding gas composition the electrode wire composition has also a great influence on the weld quality. Its selection, as a rule, is defined by conditions of the welded joint service. For welding of dissimilar steels the welding wires of $08 \mathrm{Kh} 20 \mathrm{~N} 25 \mathrm{M} 3 \mathrm{G} 2,08 \mathrm{Kh} 25 \mathrm{~N} 40 \mathrm{M} 8 \mathrm{G} 2$ and 08Kh25N60M10G2 types have been developed [9]. The increased content of chromium and molybdenum in them is designed for prevention of hot cracks formation in the weld, and nickel is used for decreasing the martensite interlayer in the zone of fusion with a pearlite steel and de- laying the development of structural heterogeneity in this zone during service heating [1]. However, chromium and molybdenum form the spinels of $\mathrm{MeR}_{2} \mathrm{O}_{4}$ type during oxidation, where $\mathrm{Fe}, \mathrm{Mn}, \mathrm{Mg}$ elements are as $\mathrm{Me}$, and $\mathrm{Al}, \mathrm{Cr}, \mathrm{V}$, Mo are as R [10], being in solid solution of wire metal. The assumption was given that in this case the transition layer is formed between the slag and weld surface, which contributes to their strong binding [11]. Welding high-alloy wire of 08Kh20N9G7T is known, which was developed for $\mathrm{CO}_{2}$ welding of high-strength steels [12]. It found the successful application for welding of dissimilar steels [13]. The peculiar feature of its composition is the decreased content of nickel and spinel-forming elements, as well as the presence of active elements-deoxidizers such as silicon, titanium, manganese, that allows producing the weld metal without defects due to self-removal of slag crust from deposited metal surface during cooling. The insufficient content of austenizing elements in this wire limits its application for welding of dissimilar steels because of formation and development of structural heterogeneity in the zone of fusion with a pearlite steel [1].

It was found at the E.O. Paton Electric Welding Institute [14] that the secondary alloying of austenitic weld metal with nitrogen in welding of dissimilar steels allows, the same as alloying with nickel, decreasing the development of structural heterogeneity in the zone of fusion with a pearlite steel. This is explained both by austenizing capability of nitrogen and also by its effect on decrease of carbon diffusion. Moreover, the nitrogen protects the high-alloy metal from oxi- 

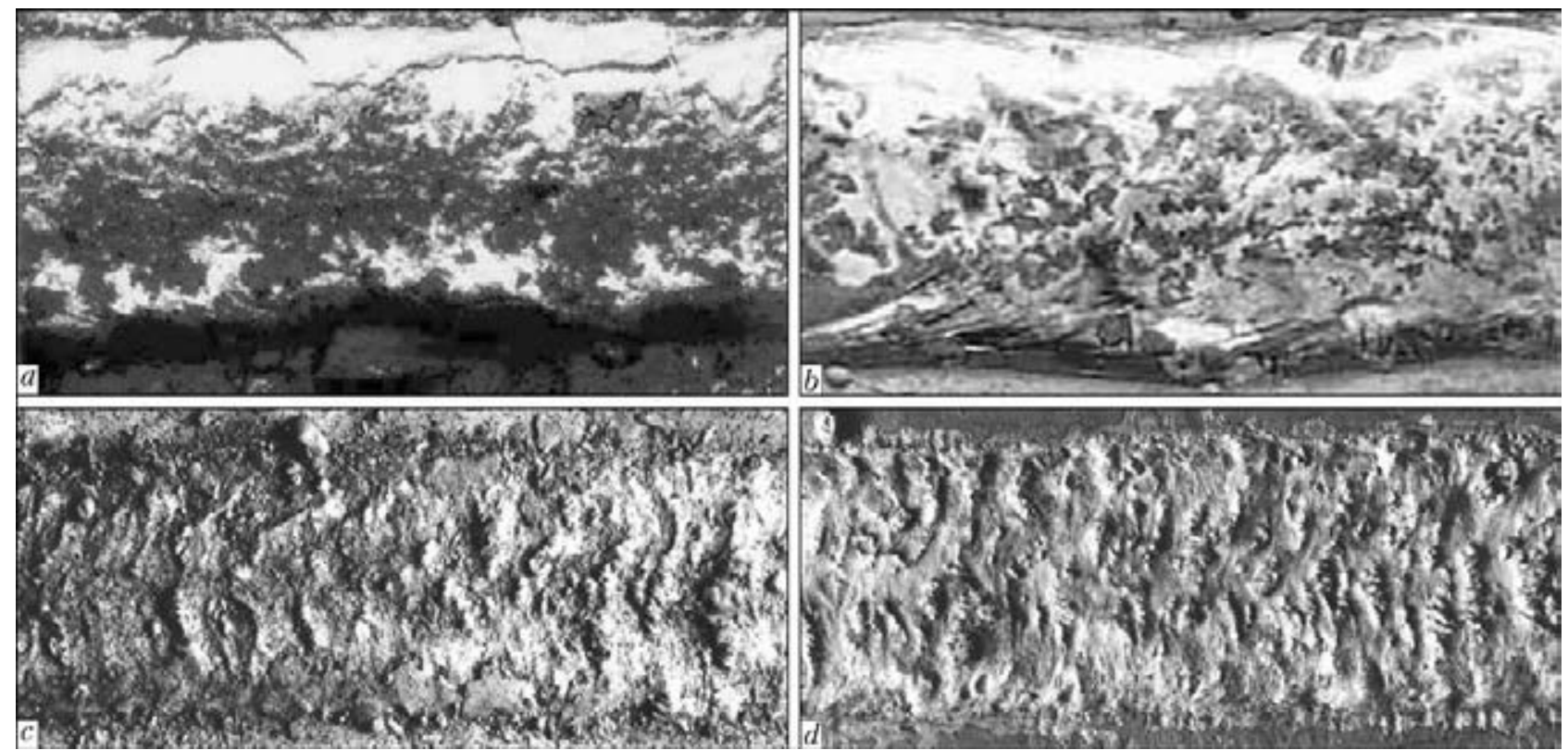

Figure 1. Appearance $(\times 2)$ of surface of deposits made by arc welding in $\mathrm{CO}_{2}+3 \% \mathrm{~N}_{2}$ using wires 08Kh20N9G7T $(a$, $b)$ and 08Kh25N40M6G2 $(c, d)$ before $(a, c)$ and $(b, d)$ cleaning

dation and provides high stability of the welding process, that prevents the formation of a slag crust on the weld surface and lacks of fusion and slag pieces in weld metal [2]. However, in the zone of fusion with a pearlite steel the pores can form [15-17], which cannot be prevented with decrease of nitrogen amount even to $0.5 \%$ in its mixture with argon. It is possible to prevent the pore formation by adding nitrogen or air to $\mathrm{CO}_{2}$ up to $14 \%$ with weld metal alloying with nitrogen in the amount of up to $0.4 \%$ [17]. The obtained results were used in the technology of arc welding of heat-resistant steels of petroleum-refining equipment using electrode wire 08Kh20N9G7T [13]. It was interesting to study the effect of nitrogen in the composition of gas mixture of $\mathrm{CO}_{2}$ and $\mathrm{O}_{2}$ on oxidation of high-alloy weld metal and slag crust removal in welding by electrode wires of $08 \mathrm{Kh} 20 \mathrm{~N} 25 \mathrm{M} 3 \mathrm{G} 2$ and 08Kh25N40M6G2 types, recommended for welding of dissimilar steels.

For this purpose, the single-layer deposits by above-mentioned wires of $2.0 \mathrm{~mm}$ diameter on plates arranged under different angles to horizon, as well as multilayer welding of $22 \mathrm{~mm}$ thick plates of $12 \mathrm{Kh} 5 \mathrm{M}$ steel in $\mathrm{CO}_{2}$ and its mixtures with nitrogen and oxygen were made. For comparison, deposits by wire of 08Kh20N9G7T type, forming a slag crust in $\mathrm{CO}_{2}$ welding possessing a good removal, were also made.

Deposits and multilayer welds were made by automatic welding machine ADG-502 at welding arc supply by direct current of reverse polarity from rectifier VDU-504. Welding current was
220-320 A, arc voltage $-24-28 \mathrm{~V}$ and welding speed - 14-20 m/h, shielding gas consumption $-121 / \mathrm{min}$

Effect of compositions of shielding gas and welding wire on metal oxidation and slag crust removal were evaluated by ratio of total amount of slag, which was collected after careful mechanical cleaning of deposit surface, to the amount of slag, self-removed from the surface of deposited metal during cooling. Results are given in Table 1, and the appearance of surface of deposits before and after cleaning is shown in Figure 1.

As is seen from this Figure, the surfaces of deposits before and after cleaning and also a slag crust, available on it, are significantly different. Surfaces of deposits, made by welding wire 08Kh20N9G7T, have smaller roughness, but they are covered with a thicker layer of a glassy-like slag, which is self-removed from the metal surface during cooling (Figure 1, a). After mechanical cleaning from remnants of slag the light surface of deposit is uncovered (Figure 1, b). However, on the surface of deposits, made by welding wire 08Kh20N25M6G7, the slag crust possesses a partial removal during cooling and hardly removed in mechanical cleaning, and with use of wire of 08Kh25N40M6G2 type it is not almost removed itself. After mechanical cleaning the deposited surface remains dark and has significant roughness due to metal hills (Figure 1, $c, d$ ). The largest amount of slag is formed on the surface of deposits made by wire $08 \mathrm{Kh} 20 \mathrm{~N} 9 \mathrm{G} 7 \mathrm{~T}$, and it is decreased with increase in level of welding wires alloying. Adding of nitrogen into shielding 
VIII INTERNATIONAL CONFERENCE «WELDING CONSUMABLES》

Table 1. Composition of slag crust formed at the weld metal surface

\begin{tabular}{|c|c|c|c|c|c|c|c|c|c|}
\hline Welding wire & Composition of shielding gas & $\mathrm{FeO}$ & $\mathrm{SiO}_{2}$ & $\mathrm{MnO}$ & $\mathrm{TiO}_{2}$ & $\mathrm{MoO}_{3}$ & $\mathrm{NiO}$ & $\mathrm{Cr}_{2} \mathrm{O}_{3}$ & $\begin{array}{l}\text { Amount of } \\
\text { slag } 10^{-3^{*}} \\
\mathrm{~g} / \mathrm{mm}^{2}\end{array}$ \\
\hline \multirow[t]{3}{*}{ 08Kh20N9G7T } & $\mathrm{CO}_{2}$ & 0.7 & 12.3 & 38.5 & 19.4 & - & - & 12.8 & $\frac{12.9(11.5)}{1.12}$ \\
\hline & $\mathrm{CO}_{2}+3 \% \mathrm{~N}_{2}$ & 0.6 & 8.3 & 32.2 & 11.3 & - & - & 6.4 & $\frac{10.5(9.3)}{1.13}$ \\
\hline & $\mathrm{CO}_{2}+3 \% \mathrm{~N}_{2}+0.5 \% \mathrm{O}_{2}$ & 0.7 & 11.4 & 36.8 & 17.4 & - & - & 11.4 & $\frac{12.7(10.8)}{1.17}$ \\
\hline \multirow[t]{3}{*}{ 08Kh20N25M6G7 } & $\mathrm{CO}_{2}$ & 16.5 & 5.6 & 38.5 & 16.5 & 1.6 & 3.25 & 26.5 & $\frac{10.1(5.11)}{1.97}$ \\
\hline & $\mathrm{CO}_{2}+3 \% \mathrm{~N}_{2}$ & 15.4 & 4.4 & 33.2 & 12.5 & 0.8 & 3.1 & 22.4 & $\frac{7.8(4.11)}{1.89}$ \\
\hline & $\mathrm{CO}_{2}+3 \% \mathrm{~N}_{2}+0.5 \% \mathrm{O}_{2}$ & 17.3 & 6.7 & 39.1 & 17.6 & 1.4 & 2.2 & 21.5 & $\frac{8.5(3.6)}{2.36}$ \\
\hline \multirow[t]{3}{*}{ 08Kh25N40M6G2 } & $\mathrm{CO}_{2}$ & 22 & 3.8 & 10.4 & 5.06 & 3.2 & 5.12 & 46.5 & $\frac{8.41(0.2)}{42.1}$ \\
\hline & $\mathrm{CO}_{2}+3 \% \mathrm{~N}_{2}$ & 19.3 & 2.8 & 9.7 & 3.3 & 2.3 & 4.2 & 38.3 & $\frac{5.2(0)}{-}$ \\
\hline & $\mathrm{CO}_{2}+3 \% \mathrm{~N}_{2}+0.5 \% \mathrm{O}_{2}$ & 21 & 3.2 & 6.4 & 4.4 & 3.1 & 4.8 & 44.3 & $\frac{7.3(0)}{-}$ \\
\hline
\end{tabular}

*Numerator gives the total and self-removed (in brackets) amount of slag, denominator - their ratio.

gas composition reduces the amount of slag, while oxygen addition increases the amount of slag, but it has not great influence on its removal (see Table 1).

Change in element composition of slag was determined by X-ray spectral fluorescence method in quantometer KRF-18. Slag, possessing a good or partial removal, has much more oxides of silicon, manganese and titanium and lower amount of iron and chromium. Attention is attracted by the fact that with increase of nickel content in the composition of wires

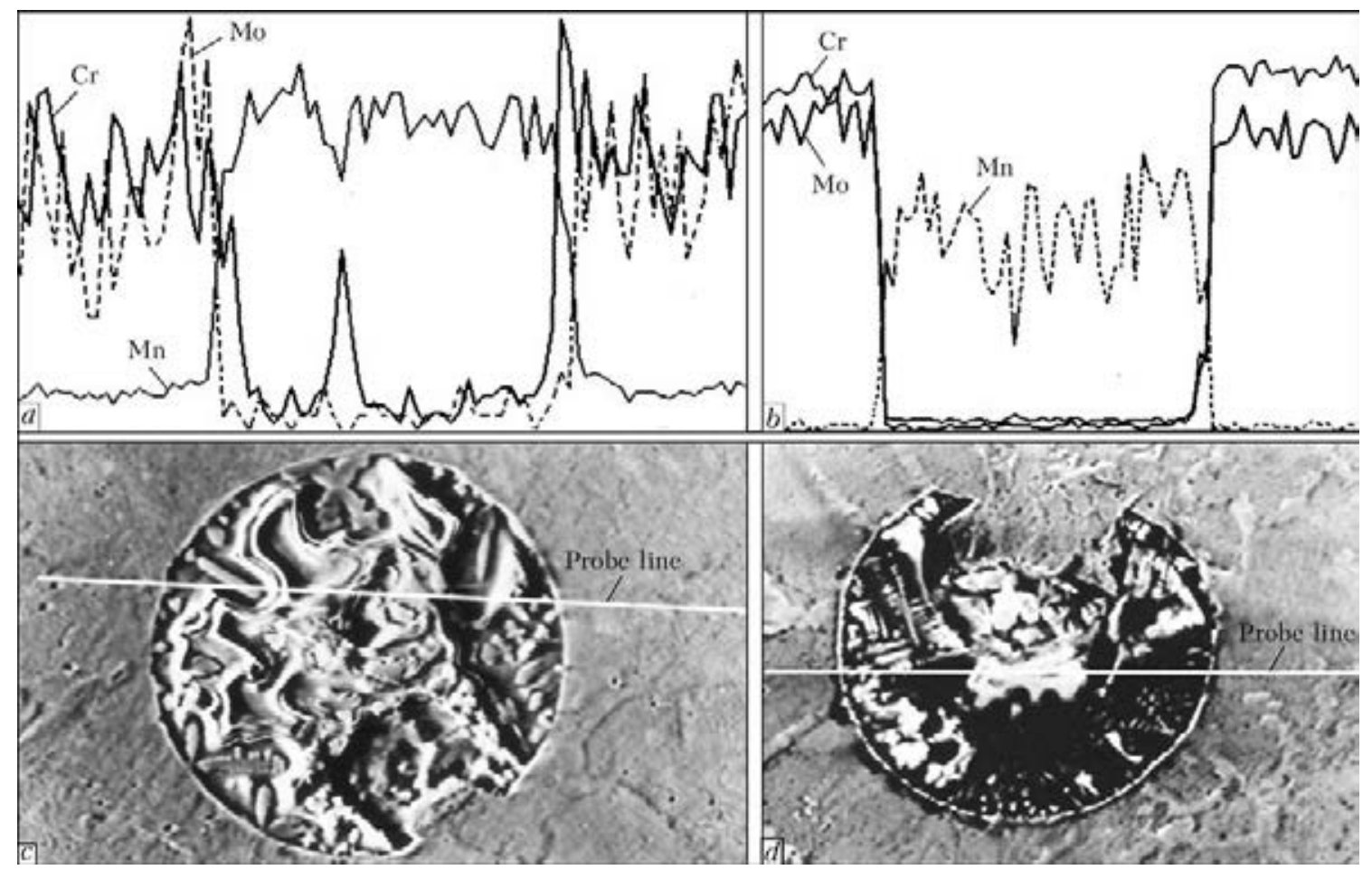

Figure 2. Distribution of chemical elements across a non-metallic inclusion located in subsurface region $(a, c)$ and lower part of deposit $(b, d-\times 1000)$ 
08Kh20N25M6G7 and 08Kh25N40M6G2 the amount of oxides of iron and nickel in the slag composition is growing. Probably, this occurs due to proceeding of silicon-manganese reduction processes on the metal surface, which can be described by the equations [10]

$$
\begin{aligned}
& \left(\mathrm{SiO}_{2}\right)_{\mathrm{sl}}+2 \mathrm{Fe}_{\mathrm{me}}=2(\mathrm{FeO})_{\mathrm{sl}}+[\mathrm{Si}] \\
& (\mathrm{MnO})_{\mathrm{sl}}+\mathrm{Fe}_{\mathrm{me}}=(\mathrm{FeO})_{\mathrm{sl}}+[\mathrm{Mn}] \\
& \left(\mathrm{SiO}_{2}\right)_{\mathrm{sl}}+2 \mathrm{Ni}_{\mathrm{me}}=2(\mathrm{NiO})_{\mathrm{sl}}+[\mathrm{Si}] \\
& (\mathrm{MnO})_{\mathrm{sl}}+\mathrm{Ni}_{\mathrm{me}}=(\mathrm{NiO})_{\mathrm{sl}}+[\mathrm{Mn}] .
\end{aligned}
$$

So, it can be assumed that with increase in content of nickel in metal the intensity of proceeding of processes of metal surface oxidation with formation of a thin oxide film is increased. Oxides of chromium and molybdenum in slag come into interaction with it, forming the chrome- and molybdenum spinels, strongly bound with metal surface.

To confirm this, the distribution of chemical elements between the metal and non-metallic inclusion was investigated by $\mathrm{X}$-ray spectral microanalysis using scanning microscope-microanalyzer CAMEBAX SX-50. Investigations were carried out on a subsurface region, located at the $0.2 \mathrm{~mm}$ distance from the surface with a slag, and on the region, located in the lower section of bead, deposited by wire 08Kh25N40M6G2 in $\mathrm{CO}_{2}$ (for results of investigations see Figure 2, $a, b)$. Table 2 shows microchemical heterogeneity and change in degree of liquation of elements in

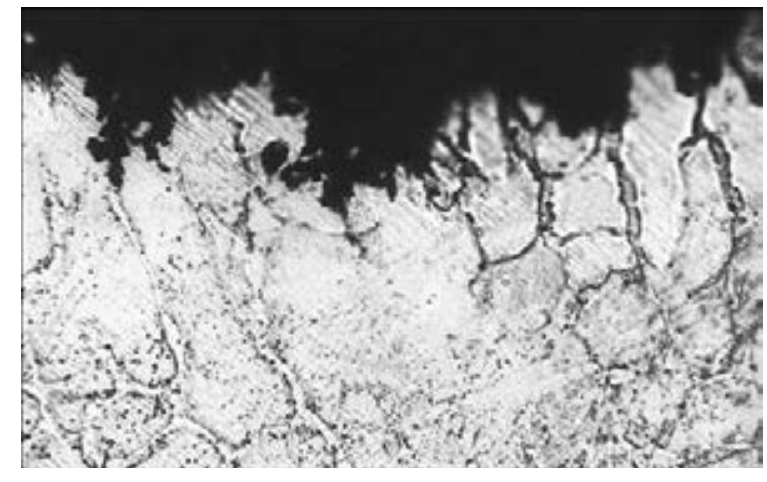

Figure 3. Microstructure $(\times 400)$ of subsurface region of metal deposited by wire 08Kh25N40M6G2 in mixture $\mathrm{CO}_{2}+3 \% \mathrm{~N}_{2}$

subsurface region at $0.1-0.2 \mathrm{~mm}$ distance from surface and in the lower part of the deposit.

Non-metallic inclusion, located in the subsurface region, has no gap with metal around its entire perimeter (see Figure 2, a). Moreover, there are peaks in curves of chromium and molybdenum distribution at the regions of transition from metal to inclusion, proving the increased content of these elements. Such local increase in their amount at the region of transition from metal to non-metallic inclusion, located in the deposit lower part, is not observed and, moreover, it has a gap with metal at the largest part of perimeter (see Figure 2, $b$ ).

The increased amount of chromium and molybdenum at the regions of transition from metal to inclusion in subsurface zone proves long duration of high-temperature heating of metal of

\begin{tabular}{|c|c|c|c|c|c|c|c|c|c|}
\hline \multirow{2}{*}{\multicolumn{3}{|c|}{ Object of investigation }} & \multicolumn{7}{|c|}{ Elements, wt.\% } \\
\hline & & & $\mathrm{C}$ & $\mathrm{Si}$ & Mo & $\mathrm{Cr}$ & $\mathrm{Mn}$ & $\mathrm{Ni}$ & $\mathrm{Fe}$ \\
\hline \multirow{6}{*}{$\begin{array}{l}\text { Deposition in } \\
\mathrm{CO}_{2}\end{array}$} & \multirow{3}{*}{$\begin{array}{l}\text { Subsurface } \\
\text { part of bead }\end{array}$} & Inter-dendrite region $\left(C_{\mathrm{tr}}\right)$ & 0.283 & 0.216 & 5.65 & 10.28 & 3.12 & 14.1 & 67.6 \\
\hline & & Dendrite $\left(C_{\mathrm{b}}\right)$ & 0.075 & 0.13 & 3.086 & 9.09 & 2.23 & 13.69 & 73.13 \\
\hline & & $\begin{array}{l}\text { Degree of liquation } \\
\left(C_{\mathrm{tr}} / C_{\mathrm{b}}\right)\end{array}$ & 3.77 & 1.66 & 1.83 & 1.13 & 1.4 & 1.03 & 0.92 \\
\hline & \multirow{3}{*}{$\begin{array}{c}\text { Lower part of } \\
\text { bead }\end{array}$} & Inter-dendrite region $\left(C_{\mathrm{tr}}\right)$ & 0.501 & 0.257 & 3.78 & 11.02 & 4.23 & 13.78 & 68.35 \\
\hline & & Dendrite $\left(C_{\mathrm{b}}\right)$ & 0.19 & 0.185 & 2.79 & 10.31 & 3.4 & 13.1 & 72.53 \\
\hline & & $\begin{array}{l}\text { Degree of liquation } \\
\left(C_{\mathrm{tr}} / C_{\mathrm{b}}\right)\end{array}$ & 2.62 & 1.39 & 1.41 & 1.07 & 1.24 & 1.05 & 0.94 \\
\hline \multirow{6}{*}{$\begin{array}{l}\text { Deposition in } \\
\text { mixture } \\
\mathrm{CO}_{2}+3 \% \mathrm{~N}_{2}\end{array}$} & \multirow{3}{*}{$\begin{array}{l}\text { Subsurface } \\
\text { part of bead }\end{array}$} & Inter-dendrite region $\left(C_{\mathrm{tr}}\right)$ & 0.203 & 0.156 & 5.35 & 9.05 & 3.08 & 13.5 & 63.6 \\
\hline & & Dendrite $\left(C_{\mathrm{b}}\right)$ & 0.065 & 0.11 & 3.186 & 8.03 & 2.36 & 12.91 & 70.63 \\
\hline & & $\begin{array}{l}\text { Degree of liquation } \\
\left(C_{\mathrm{tr}} / C_{\mathrm{b}}\right)\end{array}$ & 3.53 & 1.41 & 1.68 & 1.127 & 1.3 & 1.046 & 0.9 \\
\hline & \multirow{3}{*}{$\begin{array}{c}\text { Lower part of } \\
\text { bead }\end{array}$} & Inter-dendrite region $\left(C_{\mathrm{tr}}\right)$ & 0.491 & 0.223 & 4.73 & 11.02 & 3.93 & 13.55 & 69.88 \\
\hline & & Dendrite $\left(C_{\mathrm{b}}\right)$ & 0.187 & 0.175 & 2.51 & 10.11 & 3.1 & 12.9 & 71.54 \\
\hline & & $\begin{array}{l}\text { Degree of liquation } \\
\left(C_{\mathrm{tr}} / C_{\mathrm{b}}\right)\end{array}$ & 2.62 & 1.27 & 1.48 & 1.09 & 1.26 & 1.05 & 0.97 \\
\hline
\end{tabular}
this zone, during which the transfer of these ele-

Table 2. Microchemical heterogeneity of regions of metal deposited by wire of $08 \mathrm{Kh} 25 \mathrm{~N} 40 \mathrm{M} 6 \mathrm{G} 2$ type in $\mathrm{CO}_{2}$ and in mixture $\mathrm{CO}_{2}+$ $+3 \% \mathrm{~N}_{2}$ 
ments is occurred to the regions of proceeding of intensive oxygen-reduction processes. This is also confirmed by the results of investigation of chemical microheterogeneity (see Table 2).

Metal of the subsurface region as compared to the lower region is depleted in carbon, silicon, manganese and chromium, but enriched in molybdenum and nickel, here the degree of liquation of almost all the elements in metal near the surface is higher due to their higher amount in inter-dendrite regions than in the dendrite body. This is also proved by microstructure of the subsurface region (Figure 3). In metal layer of up to $0.5 \mathrm{~mm}$ thickness the enlargement of interdendrite regions and formation of oxidation regions in it are observed. This is correlated with the results of investigations of microchemical heterogeneity (see Table 2). Metal alloying with nitrogen did not almost influence the microchemical heterogeneity of regions being investigated.

Thus, it can be stated that oxygen-reduction processes are proceeding mainly in the inter-dendrite regions of austenitic weld metal in the subsurface region. Increase in amount of nickel in metal increases their intensity with the formation of oxides of chromium and molybdenum of the spinel type, that deteriorates the slag crust removal. Alloying of metal with nitrogen has no significant effect on these processes and, therefore, does not deteriorate the slag crust removal.

\section{Conclusions}

1. Feasibility of application of mixtures $\mathrm{CO}_{2}+$ $+3 \% \mathrm{~N}_{2}$ and $\mathrm{CO}_{2}+3 \% \mathrm{~N}_{2}+0.5 \% \mathrm{O}_{2}$ as a shielding gas in mechanized welding of dissimilar steels is shown.

2. In welding by electrode wire of 08Kh20N9G7T type in gas mixtures $\mathrm{CO}_{2}+$ $+3 \% \mathrm{~N}_{2}$ and $\mathrm{CO}_{2}+3 \% \mathrm{~N}_{2}+0.5 \% \mathrm{O}_{2}$ the formed slag crust is self-removed from the weld surface and weld is produced without lacks of fusion and slag pieces.

3. The higher content of nickel in welding wires, as well as the presence of molybdenum, deteriorate the slag crust removal due to increase in intensity of oxygen-reduction processes mainly in the inter-dendrite regions of the austenitic weld metal and formation of oxides of chromium and molybdenum of a spinel type. The defect-free weld is possible in this case only at the careful mechanical layer-by-layer cleaning of the weld surface.

4. Metal alloying with nitrogen has no great influence on the proceeding of oxygen-reduction processes on the austenitic weld metal surface and, therefore, does not deteriorate the slag crust removal.

1. Gotalsky, Yu.N. (1992) Welding of pearlitic steels by austenitic materials. Ed. by K.A. Yushchenko. Kiev: Naukova Dumka.

2. Dyatlov, V.I., Korinets, I.F. (1968) Automatic nitrogen-shielded welding of austenitic chrome-nickel steels and alloys. Avtomatich. Svarka, 9, 25.

3. Kakhovsky, N.I. (1975) Welding of high-alloy steels. Kiev: Tekhnika.

4. Nechaev, V.A., Timofeev, M.M., Rubennik, Yu.I. (1974) Influence of welding parameters on absorption of nitrogen by metal in non-shielded arc welding with high-alloy austenitic wire. Svarochn. Proizvodstvo, 4, 24-26.

5. Lopukhov, Yu.I., Ivnitsky, B.P., Sorokin, G.A. (1989) Gas-arc surfacing of fittings in nitrogenous shielding atmosphere. Energomashinostroenie, 9, 33-35.

6. Kotvitsky, A.D. (1974) Shielded-gas welding. Moscow: Vysshaya Shkola.

7. Lettle, K., Stapon, G. (2005) How to simplify the choice of shielding gas. Practical Welding Today, 9(1), 22-25.

8. Herold, H. et al. (2005) The use of nitrogen gas at welding of heat-resistant nickel alloys. Austral. Welding J., Vol. 50 (2nd quart.), 40-47.

9. Gotalsky, Yu.N., Snisar, V.V. (1970) Wires for welding of dissimilar steels. Svarochn. Proizvodstvo, 2, 42-44.

10. Potapov, N.N. (1985) Oxidation of metals in fusion welding. Moscow: Mashinostroenie.

11. Gotalsky, Yu.N., Stretovich, A.D. (1976) About mechanism of slag crust adhesion with weld metal. Svarochn. Proizvodstvo, 11, 54-56.

12. Musiyachenko, V.F., Mikhoduj, L.I. (1987) Arc welding of high-strength low-alloy steels. Moscow: Mashinostroenie.

13. Elagin, V.P., Snisar, V.V., Lipodaev, V.N. (1995) Mechanized welding of steel $15 \mathrm{Kh} 5 \mathrm{M}$ without heating and heat treatment. Avtomatich. Svarka, 8, 19-24.

14. Snisar, V.V., Lipodaev, V.N., Elagin, V.P. et al. (1991) Effect of nitrogen alloying of austenitic weld on development of structural heterogeneity in fusion zone with pearlitic steel. Ibid., 2, 10-14.

15. Pidgaetsky, V.V. (1970) Pores, inclusions and cracks in welds. Kyiv: Tekhnika.

16. Grishchenko, L.V., Kiselyov, Ya.N., Petrykin, V.M. (1987) Decrease of susceptibility to pore formation in weld metal during welding with austenitic electrodes on chrome-nickel base. Voprosy Sudostroeniya, Series Welding, Issue 26, 20-24.

17. Elagin, V.P., Snisar, V.V., Lipodaev, V.N. (1993) Specifics of nitrogenous shielded gas arc welding with austenitic wires of dissimilar and pearlitic steels. Avtomatich. Svarka, 7, 12-16.

Received 14.05.2014 